\title{
Élmények a fiatal fogyasztók közösségi média posztjaiban
}

\author{
Vincze Dalma \\ Szegedi Tudományegyetem
}

\section{A TANULMÁNY CÉLJA}

A fogyasztói magatartás kutatásának egyik legfontosabb témája a fogyasztás funkciójának sokoldalú vizsgálata. A tanulmányunk célja megérteni, hogy milyen motivációk húzódnak meg a közösségi médiában láthatóvá tett fogyasztás mögött. Nehézségekbe ütközhetünk, ha arra törekszünk, hogy megragadjuk a fiatal, 18-22 éves fogyasztók fogyasztása mögött meghúzódó motivációkat.

\section{ALKALMAZOTT MÓDSZERTAN}

A kutatásra választott módszer a fotomontázzsal egybekötött mélyinterjúkra, mint hibrid kutatási módszerre (mixed method) alapozott netnográfia, egyfajta online megfigyelés. A vizsgálati alanyaink 18-22 éves Facebook és Instagram felhasználók. A megfigyelés időtartama 3 hónap.

\section{LEGFONTOSABB EREDMÉNYEK}

Ez a három hónapig tartó megfigyelés érzékelhetővé tette, hogy milyen fó érzelmek húzódhatnak meg a posztolt képek mögött. Többnyire olyan képeket láthattunk, amelyektől a megosztó örömöt érzett, vagy ami egy eredményt mutat, amire büszke. Olyan termékeket és szolgáltatásokat szeretnének fogyasztani, amelyek bármilyen módon képesek élményt nyújtani számukra, amelyektől boldogok lesznek, akár egyedül, akár közösségben. Ugyanakkor a kutatás során az is egyértelmúvé vált, hogy az alanyok egyedinek, különlegesnek akarják érezni magukat.

\section{GYAKORLATI JAVASLATOK}

Gyakorlati javaslatként kiemelendő, hogy ez a korosztály szívesen vesz igénybe olyan szolgáltatásokat, amelyek kommunikálják, hogy élményt tudnak és kívánnak nyújtani számukra. Ezt a motivációt érdemes a termékről való kommunikációs stratégiának részévé tenni. Eredményeink hasznos insightokat jelenthetnek olyan - főként szabadidős tevékenységet - szolgáltatóknak, amelyeknek fö célcsoportjuk ez a korosztály, és akik nem zárkóznak el a közösségi felületek kommunikációra való felhasználásától.

Kulcsszavak: fogyasztás, élmény, netnográfia, fotomontázs

DOI: https://doi.org/10.15170/MM.2019.53.EMOK.06 


\section{BEVEZETÉS}

A fogyasztás mindennapi életünk része, ezért érthető módon egy fontos vizsgálati kérdéskör. Annál is inkább, hogy mennyire felkelti érdeklődésünk, ha valakinek a fogyasztását nem értjük, nem tartjuk kézenfekvőnek a választást, nem látjuk a háttérben meghúzódó motivációkat. A fogyasztást vizsgáló tudományok hosszú évekig abban értettek egyet, hogy a fogyasztás fő funkciója a szükséglet kielégítése, és hogy a demonstráló fogyasztás tulajdonképpen egyenlő a státuszfogyasztással. Időközben megjelent egy újszerủ megközelítés, amely az élménynek is jelentős szerepet tulajdonít.

Kutatásaim során a Z generáció, azaz az 1995 és 2010 között született korosztály fogyasztását igyekeztem megismerni. 2016 novemberében fókuszcsoportos megkérdezéseket és csoportos kísérletet folytattam le, melyek eredményei arra engednek következtetni, hogy a Z generáció tagjai (vagy legalábbis az 1995 és 1999 között született fiatalok, az alanyaim) szívesen vesznek részt élményfogyasztásban. A jelenség mélyebb feltárásához egy tartalomelemzésre alkalmasabb módszer vált szükségessé. Ennek értelmében 2017 június augusztusában a netnográfia módszerével kívántam feltárni, hogy a Z generáció miért tartja kiemelten fontosnak a szolgáltatások élménytartalmát. Az online megfigyelés előtt a módszertan javaslata szerint feltáró jellegủ kutatást végeztem, 2017 májusában 3 alany esetében interjúval egybekötött fotomontázs technikával kívántam feltárni a fö témaköröket, a megosztott képek mögött meghúzódó érzelmeket. A kutatás során az alábbi központi kérdésre kerestem a választ: Milyen mértékben és hogyan fedezhetö fel a megosztott tartalmakban az „élmény"? Természetesen az eredmény nem általánositható, de reméltem, hogy mégis közelebb segít majd minket a megértéshez.

\section{SZAKIRODALMI ÁTTEKINTÉS}

A fogyasztás elsődleges funkciója a problémamegoldás, a szükségletkielégítés volt, de ma már nem ennyire egyértelmű a fö funkció. A fogyasztásszociológiai szakemberek, és a fogyasztással foglalkozó diszciplínák hosszú évekig abban értettek egyet, hogy a fogyasztás fó funkciója a szükséglet kielégítése, és, hogy a demonstráló fogyasztás tulajdonképpen egyenlő a státuszfogyasztással (Corrigan 1997). Időközben megjelent egy újszerü megközelítés, amely az élménynek is jelentős szerepet tulajdonít. Az élményt számos könyv és tanulmány igyekezett megragadni, hiszen korunk marketingjének egyik kulcsfogalma. Az élmény vizsgálatával számos diszciplína kezdett foglalkozni, szükséges említenünk a szociológiát, filozófiát, és pszichológiát. Kutatásaik eredményeképpen különböző definíciókkal és megközelítésekkel álltak elő, hiszen eltérőek voltak a kutatást szükségessé tévő háttérproblémák, illetve -gondolatok is. A pszichológia tudománya a csúcsélmény (Maslow 1964), illetve a flow-élmény (Csíkszentmihályi 1990) fogalmát használja. Szerinte a flow-élmény mozgatója a boldogság keresése, és létezik egy pozitív értelemben vett tökéletes élmény, amelykor az ember átszellemül, úgy érzi, hogy a saját sorsának ura. $\mathrm{Az}$ időközben a szociológiában létrehozott élménytársadalom koncepció mellé a közgazdaságtan is megalkotta a saját megközelítését, vizsgálódásaiban megjelent az élmény kérdésköre. A marketing-szakírók az 1980-as évektöl foglalkoznak explicit módon az élménnyel, annak gazdasági/gazdasági értéket hordozó aspektusával (Holbrook \& Hirschman 1982). Az 1990-es évek végén a közgazdaságtanban megfogalmazódott az élménygazdaság koncepciója (Pine \& Gilmore 1999), amely bevezeti az élményjavakat, mint új termékkategóriát.

Az élmény gazdasági értékét a Hirschmann \& Holbrook (1982) szerzőpáros vizsgálta az élménygazdasággal és élményfogyasztással foglalkozó alapművében. A szerzőpáros szerint a fogyasztás lényege a termék által nyújtott teljesítmény és a termék jelentésének birtoklása. A szerzőpáros bevezeti az élménynézőpontot, mint fogyasztási „hozzáállást”: a fogyasztás a problémamegoldáson túlmenően esztétikai élvezetet is nyújthat, lehet játékos szabadidős tevékenység, érzéki örömök tapasztalhatóak meg általa, teret ad a fantáziálásnak, és érzelmi válaszokat válthat ki. Így a fogyasztás, amely jellemezhető szimbolikus jelentéssel, hedonisztikus válaszokkal, és esztétikai kritériumokkal, módosult tudatállapotnak, ún. szubjektív tudatállapotnak nevezhető. Ezt a típusú fogyasztást élményfogyasztásként definiáljuk. A fogyasztói élmény (Consumer Experience) a hedonisztikus, élményközpontú fogyasztás részeként jellemezhető. A hedonisztikus fogyasztás - a fogyasztói magatartás élményközpontú megközelítése - esetében a haszonelv (funkcionalitás) kiegészül egy emocionális oldallal, amely lényege, hogy a termékélmény multiszenzoros, tehát sok érzékszervvel felfogható, fantáziát megmozgató, és a fogyasztó örömöt és élvezetet keres a fogyasztás során. Pavluska (2014) úgy véli, hogy a teljes fogyasztói élmény racionális és emocionális érveket is tartalmaz. A hagyományos marketingfelfogás szerint fogyasztás során a fókusz 
a termékkategóriákra esik. Ezzel szemben az élményközpontú marketingfelfogás szerint a folyamatokban rejlik az élményszerzés és élménynyújtás kulcsa, és így a fogyasztás holisztikus élmény. Az élménytényezők az ajánlatba és környezetébe épülnek be, a termék csak egy része a teljes élménynek. A fogyasztói élmény tehát a fogyasztóban kialakuló érzelmi és mentális jelenség. $\mathrm{Az}$ ajánlat elóállítói nem élményt visznek piacra, hanem annak ígéretét. A holisztikus marketingszemlélet (Kotler - Keller 2012) szerint jó alapja az élménymarketing kialakulásának, ugyanis a fogyasztói magatartás élményközpontú szemlélete egy szélesebb, integrált perspektívát igényel. Mint láthatjuk, nincs egységes élménydefiníció, ezért kutatásom során a fentebb bemutatott megközelítéseket és gondolatokat tartottam irányadónak.

\section{CÉLCSOPORT ÉS VÁLASZTOTT MÓDSZERTAN}

Mivel a fiatalok meglepően sok időt töltenek az online felületeken, akár 10-12 órát is (Guld - Maksa 2015) és fogyasztásuk láthatóvá tételének eszközeként használják azt, ezért feltételeztem, hogy az online közösségi oldalakon megosztásra kerülö képek tükrözhetik a fogyasztásukat. Úgy gondoltam, hogy az online megfigyelés, netnográfia segítségével hasznos adatokat nyerhetek. A netnográfia lebonyolítását megelőzően azonban három alkalommal, mélyinterjúval egybekötött fotomontázs technikával, azaz a kollázstechnika egyik módosulatával, fotókból alkotott montázzsal próbáltam a célcsoport élményhez és fogyasztáshoz kapcsolódó attitüdjét, az egész folyamat müködését és a kulcsszavakat feltárni. Ezt a lépést azért tartottam fontosnak, hogy belelássak, vajon melyik típusú kép megosztásának milyen attitüd, esemény, érzelem lehet a hátterében.

A netnográfia módszere ugyan az alanyok utólagos ellenőrzésének fontosságát emeli ki, én fontosnak tartottam azt is, hogy a megfigyelés megkezdése elött se essen félreértés. Horváth Mitev (2015) szerint a kollázsmódszer a marketingkutatás keretében alkalmas lehet a mai fogyasztók lelkivilágának feltérképezésére. Fö előnyei, hogy a képekből készített új kép-kapcsolatok szemléletes és újszerủ módon tárják fel a közvetlenül nem kutatható vagy megkérdezhető tartalmakat, (esetemben megosztás mögött esetlegesen rejlő elöhívott emlékeket, vagy közösségi kapcsolatokat). Másik fontos előnye a módszernek, hogy közel áll a célcsoportomhoz, hiszen a kollázs jól illeszkedik a ma jellemzően megjelenő médiajelenségek struktúrájához, és azok befogadásához. Például ilyenek a zenei videók, 30 másodperces reklámszpotok, képes magazinok, vagy a web2.0-ás alkalmazások által kínált lehetőségek az önkéntes én reprezentációra (Horváth - Mitev, 2015). Így azt a következtetést vontam le, hogy a közösségi oldalakon létrehozott egyéni profil is a sok-sok képböl együttesen alkotott „montázs”, azaz az összképek önkéntes én-reprezentációknak tekinthetőek.

A mélyinterjúk lefolytatására és a fotomontázsok elkészítésére 2017 májusában került sor. A képanyagot a közösségi oldalakon megfigyelhető ,átlagos” képekből válogattam össze, és egy Google képkeresés után hasonlóakat válogatva, kivágva adtam az alanyoknak. Az egyéni válogatás során felmerülhet a szubjektivitás korlátja, de ennek tompítására hónapokon keresztül követtem nyomon az ,átlagosan” megosztott képeket. Reményeim szerint ez közelebb vitt az elfogultság mentesebb kiválasztáshoz. Az eredeti magazinos kollázshoz képest ez már az online-kollázshoz hasonlítható, de mégis egy „offline” verziója. Korlátként megemlítendő, hogy ebben az esetben a képek már kikerültek az eredeti kontextusból, azonban ez érdemben nem befolyásolja a kollázs készítésének folyamatát, hiszen a hangsúly az alkotáson, az új jelentés -és a posztolási kontextus és szituáció- megértésén van, nem a képek forrásán. Finley (2001) szerint további előny, hogy a folyamat közben a kép egy olyan történet részévé válik, melyek az alany a saját történeteként mesél el, miközben a kéz az elmével együtt dolgozik egy feladaton. Landgarten (1993) szerint a fotomontázs segít bizonyos emlékek felidézésén, olyan érzelmek és élmények kifejezését is segíti, amelyek kizárólag szavakkal történő kifejezése nehéz. Emellett bepillantást nyerhetünk az egyén gondolkodásmódjába, hiszen az alany saját maga által kiválasztott képek az önkifejezés gazdag, szimbólumokkal teli eszköztárat kínálnak ehhez.

A netnográfia kvalitatív kutatási módszer, amely adaptálja az etnográfiai kutatási technikákat az online térbe (Kozinets 2006). A módszer másfél évtizedes, de még mindig csak szük körben alkalmazzák. Előnye, hogy a kutató természetes közegükben tudja megfigyelni nyilvánosan elérhető online kommunikációs forrásokon keresztül a fogyasztói csoportok gondolkodásmódját és döntési mechanizmusait. Sajnos a módszer alkalmazása során korlátokkal is számolni kell. A kutatási módszer sokszor etikai kérdéseket is felvet, mint például a megfigyeltek hozzájárulásának megszerzése. Ez a korlát azonban csak szó szerinti idézet felhasználásakor áll fenn, és a jelen 
tanulmány célja nem a szó szerinti hivatkozás. Ettől függetlenül alanyaim hozzájárultak ahhoz, hogy figyeljem a posztjaikat, és ezeket az adatokat összesítve felhasználjam kutatásomhoz, feltéve, hogy nem lehet majd őket azonosítani. A kutatás célja a fó tendenciák felfedezése, és így általános következtetések levonása. További korlát, hogy a dekódoláshoz ismerni kell a közeget, amelyben a beszélgetést vagy interakciót megfigyeljük. Ezt a célt szolgálta az előzetes mélyinterjú és fotomontázs technika. A megfigyelés nem résztvevő megfigyelés volt, nem vettem részt az interakciókban, nem reagáltam a megosztott tartalmakra.

A módszer további korlátja lehet az, ami egyben legnagyobb előnye is, hogy rugalmas. A nyert adatok értelmezése során azonban tekintettel kell lenni arra, hogy minthogy megfigyelésről van szó, a kis elemszám miatt nem általános érvényüek, és nem lehet belölük messzemenő következtetéseket levonni. Azonban tökéletesen megfelel egy feltáró jellegü kutatás során a fö irányvonalak megtalálására. Ezek a korlátok természetesen az én kutatásomra is igazak. Kozinets (2002) szerint a netnográfia lefolytatásának első lépcsője az ún. Kulturális Entrée, amelynek lényege, hogy előzetes információkat gyüjtsünk arról, hogy milyen felületeken folytassuk le ezt az online megfigyelést, és milyen adatokat tudunk majd így szerezni. Azon is el kell gondolkodnunk, hogy ezek az adatok megfelelnek-e minőségben és mennyiségben nekünk, illetve elérhetjük-e vele kutatási céljainkat. Kozinets (2002) és Gál és szerzőtársai (2016) több módszert is említenek a megfigyelésre, mint a keresőmotorok eredményeinek megfigyelése, a listázó oldalak, téma-specifikus „körök”, a chat szobák, és a közösségi oldalak megfigyelése. Én ez utóbbit választottam, mert korábbi eredményeim, és a szakirodalom által hangsúlyozott célcsoportomra jellemző mértékü online jelenlét is ebbe az irányba mutattak.

A mélyinterjú és fotomontázs technika három alany megosztási hajlandóságába, online viselkedésébe és attitüdjeibe engedett közvetlen betekintést. A fotomontázs során képek közül kellett három csoportot alkotni, és egy saját montázst alkotni. A három csoport:

1. amit megosztana Facebookon, vagy Instagramon (és milyen változtatásokkal),

2. amit nem osztana meg valamilyen konkrét okból (fontos, hogy mi a pontos ok),

3. és végül, amik ugyan tetszenek, de nem kerülnének megosztásra (és ez miért következik be).

A netnográfia szempontjából csak a megosztásra kerülő csoport háttér-motivációi relevánsak, de a teljesség kedvéért a másik két képcsoportról is beszéltek az alanyok. A fotomontázs során megkérdezett három alany önmaga mondta el, hogy milyen vezérelvek alapján oszt meg tartalmakat. Az említett három megkérdezett mellett további tizenhét alany online megosztási aktivitását figyeltem meg. A tizenhat említett generációból (életkori sávból: 18-22) már ismerősöm volt az oldalon, és megfelelt a megfigyelés kritériumának. A mélyinterjúk és fotomontázsok alapján úgy döntöttem, hogy az Instagram és a Facebook közösségi oldalakat veszem górcső alá. Alanyaim mindkét oldalon felhasználók, ezért erre lehetőségem volt mind a húsz alany esetében. A fö megfigyelt dimenziók:

- $\quad$ képek és videók megosztása - összesen érték alakulása oldalanként,

- hashtagek használta fóleg Instagramon ezek jellegzetességei, száma,

- Facebookon megjelenő egyéb megosztások formái.

A kutatás során az alábbi központi kérdésre kerestem a választ: Milyen mértékben fedezhetö fel a megosztott tartalmakban az ,élmény”?

\section{EREDMÉNYEKA FOTOMONTÁZSOK TÜKRÉBEN}

Ebben a részben kitérek a három fotomontázst készítő alany (Letti, Detti és Etelka) Instagramon és Facebookon történő megosztásainak azonosságaira és különbségeire annak tükrében, amit az interjú során a megosztási magatartásukról nyilatkoztak. Kiemelték, hogy szerintük a fogyasztás megváltozott, már sok mindent megveszünk, ami nem elengedhetetlenül szükséges, de örömet okoz.

Letti, 20 éves női alany, a mélyinterjú és a fotomontázs készítés során azt mondta, hogy a képek megosztásakor inkább az Instagramot használná. Tartalmukat tekintve olyan képeket élményeket szimbolizálják, ezek a képen 1-sel jelölt képcsoport. Jellemzően a nyaralás hangulatát idéző képek, a télis sportok, és kirándulások képei ennének ezek. osztana meg (1. ábra), amelyek a családjával és barátaival közösen töltött időben szerzett. 


\section{1. ábra: A Letti által készített fotomontázs}

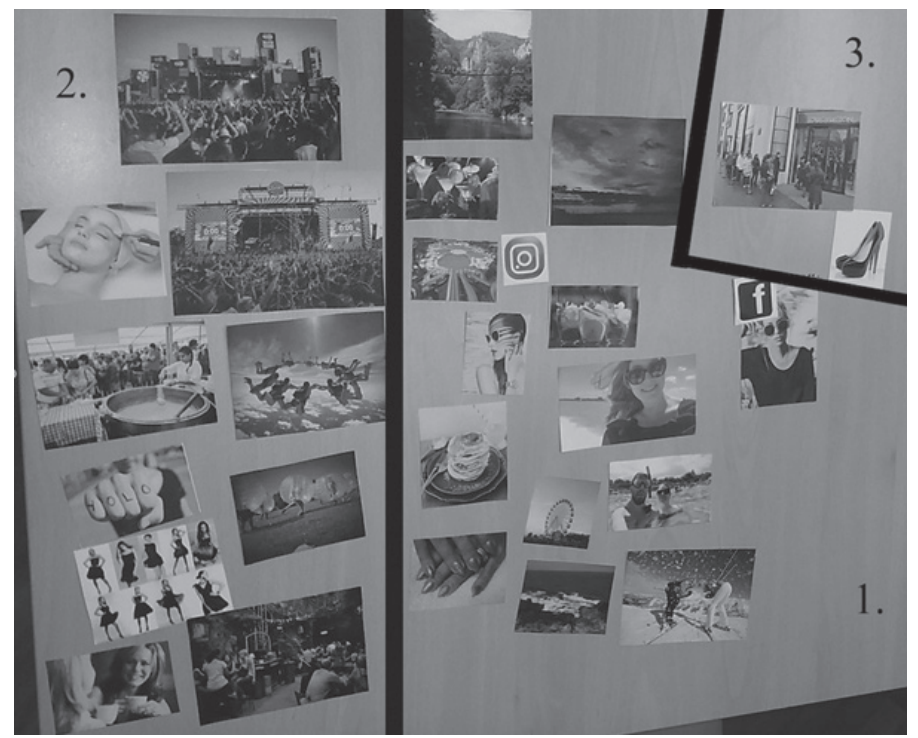

Forrás: saját szerkesztés

„A családi és baráti eseményekre emlékeztetnek ... ezeket tenném fel az Instagramra, és akkor ez olyan lenne, mint egy album. ...A fb-ra csak néha egy két képet szoktam magamról feltölteni. Ez az egy kép csak úgy megtetszett, és az arányt jelezném ezzel a Facebook és Insta között. Azt szeretném, hogy csak a közeli ismerőseim lássák. Instára ez a középsö rész (montázs középső részére mutat) menne, ez inkább albumként menne. Az a jó az Instán, hogy egyszerre látom az összes képet egész nagyban, és látom az élményeim egyszerre."

A megfigyelési időszakban Instagramon megosztott képei között valóban családi nyaralásos képeket látunk. Az alany a családdal és párjával szerepel a képeken, ételek és italok láthatóak, valamint négy nyaralás során készült tájkép, melyből kettőn ő is szerepel. A \# címkézések alapján a boldog pillanatra koncentrál (\#természet; \#horgászat; \#boldogság; \#happyday; \#szeged). Az egyéb, nem megfigyelési időszakban kiposztolt képe alapján szintén a család és szabadidő megörökitésének lehetünk tanúi. Föként szelfik láthatóak az oldalon. A Facebookon megosztott képeken szintén családi vagy baráti közös pillanatok láthatóak, együtt eltöltött minőség időt örökítenek meg. Számuk elenyésző, inkább az Instagram használata jellemzö.

Az első ábrán látható 2-sel jelölt részben találhatóak azok a képek, amelyeket nem osztana meg az alany, olyan vágyakat szimbolizál, amelyek mint egy „majd kipróbálom” listaként müködnek. Ezeket, mivel még nem történt meg, nem osztaná meg, vagy ha esetleg újra átél hasonló emléket, mint amit ezek a képek előhívtak, akkor tenné ki öket az oldalára.

„Na és ezek igazából olyan vágyak, amiket szeretnék kipróbálni. A Balaton Sound nekem az egy nagy álom, elmennék egy ilyen nagy fesztiválra, a koncerteket szeretem élöben hallgatni. A kozmetikában régen voltam, és már idöszerü, szóval ilyen határidőnapló jelleggel kerül ide. A bográcsozás élménye is eszembe jutott, és ezt a felfújt lufis vizes izét is kipróbáltam már, egész jó élmény volt. A YOLO csak simán tetszett. A koktélruhákat pedig szivesen felpróbálnám. Ami még nagyon tetszett, ez a kávézós romkocsmás kép, nem tudom megmondani, hogy miért, de a kép maga fogott meg. A kávézós hölgyes kép azért tetszett meg, mert jó a hangulata, pl. amikor anyukámmal, vagy a barátnöimmel kávézom."

A 3-sal jelölt képrészleten az a képhalmaz látható, melyet az alany nem osztana meg, saját magának se mentene le, és valamilyen negatív érzést vált ki belőle. Letti esetében ez egy Louis Vuitton márkabolt előtti sor volt és egy elegáns Yves Saint Laurent (YSL) cipő. Az alany szerint ez felesleges pénzköltésért való sorban állás, és a cipő miatt irigységet érez saját bevallása szerint. 
Detti, 21 éves női alanyom a fotomontázs készítése közben (2. ábra) elmondta, hogy ö jellemzően kevés képet oszt meg, az élményeket inkább megéli, és a fényképeket magának menti le, Instagramot ere a célra ritkábban használ.

\section{2. ábra: Detti által készített fotomontázs}

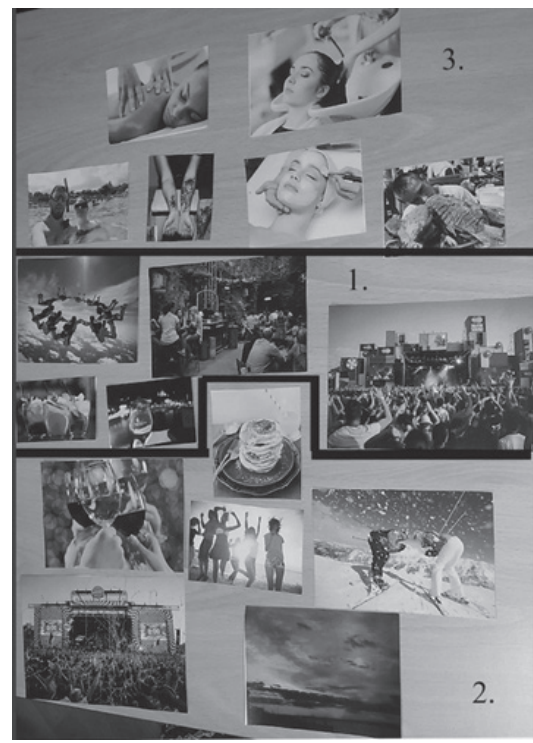

Forrás: saját szerkesztés

Az általa fotomontázsnál megosztásra választott képeket, amelyek főleg extrémsportok és fesztiválok, kulináris élmények kategóriájába tartoznak, az ,élmény” és ,, hangulat” szóval jellemezte (1-sel jelölt keretezett képek).

„Ez az ejtöernyös kép azért tetszett, mert biztos hatalmas élmény lehet, bár lehet, én félnék kiugrani, de ha megtettem, kiposztolnám, bár biztos nehéz igy képet csinálni, nem? Nekem egyébként az adrenalin szó jutott róla eszembe, mert tök jó kapcsolaterösítö lehet, hogy együtt zuhanunk. Ezeket a képeket mind azért posztolnám ki, mert nem egy hétköznapi élmény. A koktélozás is azért tetszik, mert a szinek miatt a nyár hangulata van benne. A fesztiválos kép is ilyen, jó élmény, hogy az ember élöben hallja a zenét, föleg ha azt, amit szeret is, és nem csak azért megy, hogy mutassa, hogy ott van. Egyébként ez az összes posztolásra igaz, hogy abban picit mindig benne van, hogy mutatni a többieknek."

Elmondta, hogy nem jellemző rá, hogy a meglátogatott vendéglátóipari helyek Facebook oldalán bejelentkezne, hogy ott van, inkább átéli ezeket az élményeket.
„,...) hát ha valami különleges lenne, nem azt mondom, hogy nagyon gyakran, de kiposztolnék egy képet. Bejelentkezni is nagyon ritkán szoktam, csak ha valami nagyon különleges okból vagyok ott. ... Nekem elég, hogy én tudok róla, hogy ott vagyok, nem kell bejelentkezni. Ezeket a hangulatokat nem lehet úgyse visszaadni a képpel, én inkább magam élem meg."

$\mathrm{Az}$ Instagramon a megfigyelés időszakában valóban kevés képet láthatunk, főleg szelfik és párjával készült képek. Korábbi megosztásait tekintve ételek és oklevelek láthatóak. A \# címkézések alapján valóban olyan dolgokat oszt meg, amelyek elérésére büszke (\#waffels; \#sweethome; \#datenight; \#beer). Facebookon fél éve nem volt aktív megosztása, csak eseményeket lájkolt, néhány családi eseményen jelölték be, és profilképet cserélt.

Azok a képek, melyek a fotomontázsos interjú kapcsán nem kerültek megosztásra, mert nem tenné ki, a 2-sel jelzett részen láthatóak a 2. ábrán. Az alany szerint ezek olyan pillanatok, hogy másoknak nem mondd semmit, ezért nem tenné ki, de saját magának megőrizné emlékbe, vagy inspirációként a jövőre nézve. A 3-sal jelzett részen 
pedig azoknak a képeknek halmaza, amelyeket az alany „túl intim” vagy túl „,bugyuta” jelzővel illet, így semmiképpen sem kerülnének ki semmilyen közösségi oldalra.
Etelka, 20 éves női alanyom a fotomontázs képek kiválasztása során (3. ábra) azt mondta, hogy az Instagramra jellemzöen bizalmasabb képeket töltene fel, míg a Facebookra szélesebb rétegnek látható képek is felkerülhetnek.

\section{3. ábra: Etelka által készített fotomontázs}

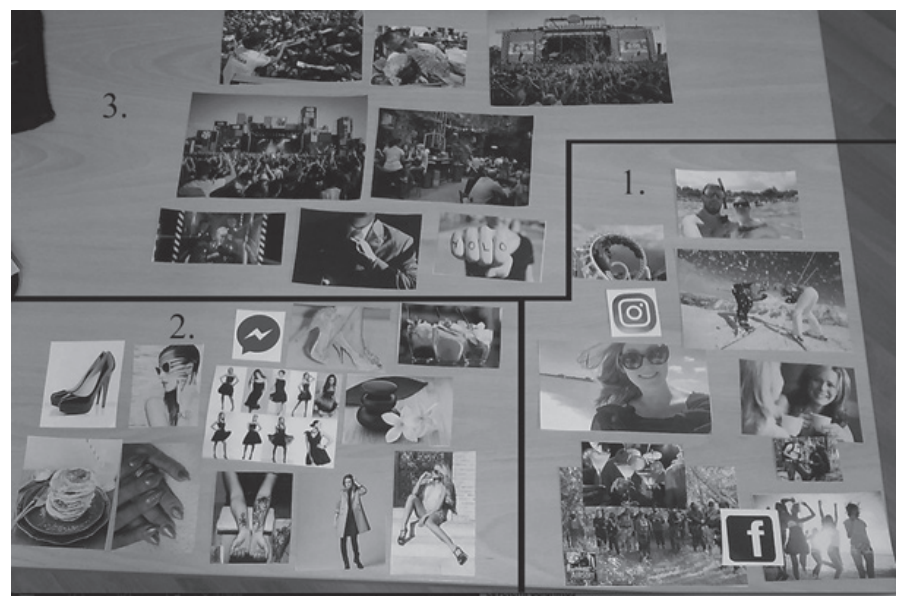

Forrás: saját szerkesztés

A megosztott képek (1-sel jelzett rész) témáit tekintve megjelölte az extrém spotokat, nyári- és téli sportokat, a borfesztiválokat, és a szabadidős tevékenységeket, valamint a párjával közös fotókat.

„,Most már csak olyan 1-2 nagyon fontos dolgot teszek ki a Facebookra, és Instagramra kicsivel többet. A kettö között az a különbség tulajdonképpen, hogy Facebookon, akivel egyszer is beszéltem, az az ismerösöm. Instagramon meg inkább olyanoknak engedem, hogy kövessenek, akik közel állnak hozzám. Facebookon inkább a nevesebb eseményeket, Instagramon pedig inkább a belsőségesebbeket osztom meg. Ezeket itt kitenném, hogy velük voltam, ezt csináltam, jól éreztük magunkat. Ezeket ugye így mindenki láthatná egy közösségi oldalon."

Az Instagramon a megfigyelés időszakában két kép került megosztásra, mely a párjával a nyaralás során készült. A korábban megosztott képeket tekintve jellemző a nyaraláson és neves alkalmakon készített képek és szelfik megosztása. A \# címkézések egyediek, hosszúak és összetettek (\#nagycsalád; \#ezcsakakezdetvolt; \#édesem; \#szerelem; \#kethetbalaton). A Facebookon a megfigyelési időszakban nem osztott meg képet, inkább csak érdekes linkeket és eseményeket lájkolt.
A fotomontázs során az alanynak a 2-sel jelzett részben lévő képek tetszettek, de nem osztaná meg öket, inkább inspirációként mentené le magának, vagy másnál lájkolná. vagy elküldené ismerőseinek inkább privát üzenetben:

„, (...) a messenger ikon pont azt jelzi itt ezeknél, hogy ha ezeket meglátom, beszélgetek róla másokkal, vagy például ezt a kaját én csináltam, vagy láttam egy jó körmöt, akkor lefotózom, és elküldöm a barátnömnek, hogy nézd, ezt találtam (...)."

A 3-sal jelzett részben lévő képek vagy egyszerű unszimpátia miatt nem kerülnének ki, mint például a halas kép, vagy azért, mert az alany nem szeretné, hogy tudják, hogy éppen hol tartózkodik. Meglepő módon helyet kapott a nem megosztandó képek között két zenei fesztivál képe is. Az alany azt mondja, neki nincsenek jó érzései a fesztivállal kapcsolatban:

„Hát ez nekem azt jelképezi, hogy nem szeretem a fesztiválokat, nem jó érzéseim vannak róla (...) ott lakom a közelében, és nem szeretem, ahogy dübörög. Úgy gondolom, hogy az a rengeteg ember, aki tolong és egymást tapossák a sárba és van ott egy énekes és mindenki bálványozza, én meghallgatom az interneten és nem hoz lázba.... na meg rengeteg pénzbe kerül, hogy az ember ott legyen egy hétig." 
$\mathrm{Az}$ Instagramon és Facebookon figyelemmel kísértem további tizenhét ember megosztásait az említett időszakban. Ismerőseim voltak, így némileg következtetni tudtam, hogy milyen életesemény „szülte” a megosztott képet és hogy lehet értelmezni a \#-eket. Az alábbi táblázatban összefoglalom, hogy milyen jellemzőkkel bírnak az alanyok, és milyen tartalmakat osztottak meg az egyes platformokon. A felhasznált nevek álnevek, nem egyeznek meg az alany valódi nevével. A táblázatban (1. táblázat) egyértelmúen látszik, hogy melyik felületen milyen típusú képek és tartalmak felfedezhetőek.

Leggyakrabban a családi fotók, az olyan események megörökített képe került megosztásra, amelyek a három mélyinterjú és fotomontázs alany oldalán is megtekinthetőek. Kiemelendö, hogy az Instagramon megosztott képekre igaz a fotomontázs készítő alanyok által is említett motiváció. Az Instagram felületén több kép és videó került megosztásra, és gyakoribb a használata, mint a Facebooknak, az összes alany megosztásait tekintve.
A megosztott képek és videók között nagy számban családi eseményeket, nyaralási fotókat, vagy ételeket-italokat látunk, extrém sportokat és szabadidős tevékenységeket láthatunk. Kiemelném, hogy a VOLT, a Balaton Sound, a Sziget, és a SZÍN fesztiválokon készitett képek és videók is feltüntek a profilokon. A képek többségén extrém sportok (bungee jumping, vitorlásrepülőzés), vagy szép tájak, „hangulatok” (ételek és italok is) láthatóak. Valószínü a \# használatból (címkézésből), hogy az átélt élményt és érzelmeket próbálták egy fényképpel vagy videóval megörizni. Jellemző, hogy inkább az Instagramon találhatóak meg ezek a képek, a Facebookon jellemzöen csak csoportképek, szelfik és tájképek jelennek meg, illetve vicces képek, mémek. A Facebook profilok így „személytelenebb” hatást keltenek. Jellemző még, hogy a Facebook profilokon az Instagramról átemelt képek jelennek meg.

\section{1. táblázat: Az alanyok adatai és néhány fontosabb adat}

\begin{tabular}{|c|c|c|c|c|c|c|}
\hline Alany neve & Születési év & Nem & $\begin{array}{c}\text { Összes } \\
\text { kép/ } \\
\text { video (db) } \\
\text { Instagram }\end{array}$ & $\begin{array}{l}\text { Összes \# } \\
\text { (db) }\end{array}$ & Érdekes használt \# & $\begin{array}{c}\text { Összes } \\
\text { kép/ } \\
\text { video (db) } \\
\text { Facebook }\end{array}$ \\
\hline Letti & 1996 & nő & 64 & 35 & $\begin{array}{l}\text { \#SZIN \#fesztivál:) \#Bala- } \\
\text { ton \#Siófok \#lakodalom }\end{array}$ & 25 \\
\hline Detti & 1996 & nő & 4 & 6 & $\begin{array}{c}\text { \#coctail \#sexonthebeach; } \\
\text { \#waffles \#blueberry } \\
\text { \#sweethome }\end{array}$ & 2 \\
\hline Etelka & 1995 & nő & 2 & 16 & $\begin{array}{c}\text { \#mylove \#balcsi \#6.5év } \\
\text { \#exams \#kethetbalaton } \\
\text { \#family \# pihi \#happy }\end{array}$ & 3 \\
\hline Laura & 1995 & nő & 6 & 22 & $\begin{array}{c}\text { \#summer \#nemakarok- } \\
\text { hazamenni \#balaton } \\
\text { \#hajókázás }\end{array}$ & 4 \\
\hline Gábor & 1996 & férfi & 13 & 30 & $\begin{array}{l}\text { \#piknik summer \#buda- } \\
\text { pest \#mik \#afternoonwalk }\end{array}$ & 2 \\
\hline Jácint & 1997 & férfi & 6 & 0 & - & 2 \\
\hline Mercédesz & 1996 & nő & 13 & 7 & $\begin{array}{c}\text { \#ilovenyc \#warsaw \#tra- } \\
\text { vel \#budapest \#hungary } \\
\text { \#mutimiteszel }\end{array}$ & 3 \\
\hline Kamilla & 1996 & nő & 10 & 25 & $\begin{array}{c}\text { \#sweet20 \#sightseeingday } \\
\text { \#familyholiday museum } \\
\text { \#amphiteatre }\end{array}$ & 6 \\
\hline
\end{tabular}




\begin{tabular}{|c|c|c|c|c|c|c|}
\hline Alany neve & Születési év & Nem & $\begin{array}{c}\text { Összes } \\
\text { kép/ } \\
\text { video (db) } \\
\text { Instagram }\end{array}$ & $\begin{array}{l}\text { Összes \# } \\
\text { (db) }\end{array}$ & Érdekes használt \# & $\begin{array}{c}\text { Összes } \\
\text { kép/ } \\
\text { video }(\mathbf{d b}) \\
\text { Facebook }\end{array}$ \\
\hline Dalma & 1995 & nő & 19 & 22 & $\begin{array}{c}\text { \#fun \#friend \#crazy \#girls } \\
\text { \#coctail }\end{array}$ & 4 \\
\hline Stella & 1999 & nö & 2 & 0 & - & 2 \\
\hline Dominik & 1997 & férfi & 4 & 4 & $\begin{array}{c}\text { \#langolnivagyom \#smoke } \\
\text { \#forpresident }\end{array}$ & 2 \\
\hline Bence & 1995 & férfi & 1 & 5 & $\begin{array}{l}\text { \#cat \#catlover \#meow } \\
\text { kings \#pegasus }\end{array}$ & 2 \\
\hline Rebeka & 1996 & nő & 6 & 5 & $\begin{array}{c}\text { \#voltfestival \#vegreszin } \\
\text { \#chill \#suncity }\end{array}$ & 2 \\
\hline Kornél & 1995 & férfi & 3 & 2 & \#light \#nice & 2 \\
\hline Bianka & 1995 & nő & 18 & 17 & $\begin{array}{c}\text { \#lastnight \#wassogood } \\
\text { \#elegant \#mom \#love } \\
\text { \#engagement \#traccsparty }\end{array}$ & 3 \\
\hline Anton & 1995 & férfi & 10 & 13 & $\begin{array}{c}\text { \#hoppegyesküvő \#sziget } \\
\text { \#bp \#tenger }\end{array}$ & 2 \\
\hline Anikó & 1996 & nő & 1 & 1 & \#ujvagyokitt & 2 \\
\hline Dorina & 1998 & nö & 12 & 26 & $\begin{array}{l}\text { \#best \#love \#friendship } \\
\text { \#happy \#sun \#blackismy- } \\
\text { colour }\end{array}$ & 2 \\
\hline Tamás & 1995 & férfi & 3 & 3 & $\begin{array}{l}\text { \#nicebulilding \#somet- } \\
\text { hingclear }\end{array}$ & 3 \\
\hline Veronika & 1996 & nő & 5 & 5 & $\begin{array}{c}\text { \#beginningofanewlife } \\
\text { \#concert \#music \#szin } \\
\text { \#havefun }\end{array}$ & 1 \\
\hline Összesen & - & - & 202 & 244 & - & 74 \\
\hline Átlagosan & 1996 & - & 10 & 12 & - & 3 \\
\hline
\end{tabular}

Forrás: saját szerkesztés

Az alanyok igyekeznek olyan képeket feltenni ezekre az oldalakra, melyek boldogságot vagy büszkeséget váltanak ki belölük. Ezt támasztja alá, hogy életeseményeket, okleveleket, nagyobb eredményeket (akár családi esemény, akár karrier cél megvalósulása) is láthatunk képekben tükröződni. A Facebookon jellemző még az egyéb, nem kép és videó megosztási tevékenység megjelenése. Például, cikkek linkjei, zenei klippek, nyereményjátékok is nagy számban megjelennek, ami arra enged következtetni, hogy a facebookos profilok inkább az informálódás és kapcsolatban maradás, közösségbe kapcsolódás eszköze, míg az instagramos profilok célja az én bemutatása, megmutatása a mások felé.
Íme néhány összesített adat a megfigyelési időszak során nyert adatokról:

- Összesen 10 nő és 7 férfi alany online megosztásait figyeltem meg.

- $\quad$ Az Instagramon az alanyok átlagosan 307 embert követnek, és 244 tag követi öket.

- A 20 alany összesen 244 kettős keresztet használt a megosztott tartalmak generálására.

- A megfigyelési időszak alatt az Instagramon összesen $202 \mathrm{db}$, a Facebookon pedig 281 darab megosztás történt.

- Habár a Facebookon nagyobb számmal történt megosztás, szükséges megjegyeznünk, hogy a 281 tartalomból csak 134 volt kép illetve videó, amelyekbe a zenei videók is beletartoznak. A többi tartalom jellemzően linkek, események, mémek. 


\section{ÖSSZEFOGLALÁS ÉS TOVÁBBI IRÁNYOK}

A kutatás során kvalitatív módszerrel vizsgáltam a Z generáció (pontosabban 1995-1999 között születettek) szimbolikus fogyasztását. Korábban fókuszcsoportos megkérdezéseket és csoportos kísérletet folytattam le, melyek eredményei arra engednek következtetni, hogy ez a korosztály élményfogyasztásban élen jár. Ezt a jelenséget mélyebben feltárni képes módszer alkalmazása is szükségessé vált: egy tartalomelemzésre képes módszer alkalmasabb lehet az élményfogyasztás vizsgálatára. A netnográfia módszerét alkalmaztam, ezt megelőzően azonban három darab mélyinterjúval egybekötött fotomontázs-kollázs technikával próbáltam a célcsoport élményhez és fogyasztáshoz kapcsolódó attitűdjét, és az egész folyamat müködését, és a kulcsszavakat feltárni. Ez azért volt fontos, hogy bele lássak vajon melyik típusú kép megosztásának milyen attitűd lehet a hátterében. A mélyinterjúk lefolytatására és a fotomontázsok elkészítésére 2017 májusában került sor. Az alanyok a fotomontázs készítése közben elmondták, hogy szerintük léteznek tipikus termékek és szolgáltatások, melyek „arra lettek kitalálva”, hogy az ember megnövekedett élményszerzési vágyát kielégítsék. Ezek lehetnek: extrém sportok, téli vagy nyári sportok, utazás, különbözö kulturális és zenei fesztiválok, minöségi idö eltöltése a családdal, vagy barátokkal, de akár valamilyen kulináris élvezet is. Főleg szolgáltatások jelentek meg, mint a mozi, szinház, fesztiválok, extrémsportok, romkocsmák és szabaduló szobák, emellett pedig a fodrász, mükörmös, és ételek-italok is. Fontos azonban, hogy jó érzéssel töltse el a fogyasztót, és hogy láthatóvá válhasson online, közösségi oldalakon, vagy személyesen lehessen róla mesélni, és legalább egy fénykép készüljön róla. A fotomontázst a mélyinterjúk után közvetlenül készítettem el az alanyokkal. Három csoportba válogathattak képeket, melyet megosztanának; melyeket nem; és melyek tetszenek, de nem kerülnének megosztásra. Jellemző a „megosztott” képekre, hogy egy családdal vagy barátokkal, esetleg egyedül átélt élmény, kulináris élvezet vagy szórakoztató szabadidős tevékenység megörökítése a célja. Fontos, minden alany számára, hogy az ismerösei szük köre láthassa csak a képeit.
2017 júniusa és augusztusa között online megfigyelést, ún. netnográfiát végeztem. A netnográfia során a három fotomontázst készítő alany és további 17 , tehát összesen 20 fö Instagram és Facebook profilján megosztott képeket és videókat követtem nyomon. Az alanyok 1995 és 1999 között születtek. Az eredmények összességében azt mutatják, hogy a megosztott képek és videók között valóban családi eseményeket, nyaralási fotókat, vagy ételeket- italokat látunk. Kiemelném, hogy a VOLT és a Balaton Sound fesztiválokon készített képek és videók is feltűntek a profilokon. Ezeken többnyire extrém sportok (bungee jumping), vagy szép tájak, „hangulatok” láthatóak. Valószínủ a \# használatból (címkézésből), hogy az élményt próbálták egy fényképpel vagy videóval megőrizni. Jellemző, hogy inkább az Instagramon találhatóak meg ezek a képek, a Facebookon inkább csak csoportképek, szelfik és tájképek jelennek meg, illetve vicces képek, mémek. A Facebook profilok így „személytelenebb” hatást keltenek.

A kutatás megerősítette, hogy az általam elért fiatalok életében fontos az élményfogyasztás, de szeretném eredményeimet kvantitatív úton is ellenőrizni, és egy modellt építeni, amely igazolhatja és magyarázhatja az élményfogyasztást a $Z$ generáció - mint kiterjesztett célcsoport - esetében. 


\section{HIVATKOZÁSOK}

Corrigan, P. (1997), The sociology of consumption, London: Sage

Csíkszentmihályi, M. (1990), Flow. The Psychology of Optimal Experience, New York: Harper Collins

Finley, S. (2001), "Painting life histories" Journal of Curriculum Theorizing, Summer, 123-62

Gál T. - Soós M. - Szakály Z. (2016), „Online fogyasztói csoportok azonosítása az egészségtudatos táplálkozás terén netnográfiai kutatással," in: Fehér A. - Kiss V. Á. - Soós M. - Szakály Z. (szerk.), EMOK XXII. Országos Konferencia Hitelesség és Értékorientáció a Marketingben, Debrecen, 119-27

Guld Á. - Maksa Gy. (2015), „Fiatalok kommunikációjának és médiahasználatának vizsgálata." in: Törőcsik M., (szerk.), A Z generáció magatartása és kommunikációja, Pécs, Pécsi Tudományegyetem, 52-65

Hirschman, E. C., Holbrook, M. B (1982), ’Hedonic consumption: emerging concepts, methods and proposititons", Journal of Marketing 46 3, 92-101 DOI: https://doi.org/10.2307/1251707

Holbrook, M. B., Hirschman, E. C. (1982), "The experimental expects of consumption: Cunsumer fantasies, feelings and fun", Journal of Consumer Research, 9 2, 132-40 DOI: https:// doi.org/10.1113/expphysiol.2007.037523

Horváth D. - Mitev A. (2015), „Kollázstechnika, képasszociációk", in: Horváth D. - Mitev A. (szerk.), Alternatív kvalitatív kutatási kézikönyv, Budapest: Alinea, 337-56

Kotler, P. - Keller, K. L. (2012), Marketingmenedzsment, Budapest: Akadémiai Kiadó

Kozinets, R. V. (2002), "The Field Behind the Screen: Using Netnography For Marketing Research in Online Communities", Journal of Marketing Research, 39 1, 61-72 DOI: https:// doi.org/10.1509/jmkr.39.1.61.18935

Kozinets, R. V. (2006), "Click to Connect: Netnography and Tribal Advertising", Journal of Adverising Research, 46 3, 279-88 DOI: https:// doi.org/10.2501/s0021849906060338
Landgarten, H. B. (1993), Magazine photo collage: A multicultural assessment and treatment technique, New York: Brunner/Mazel

Maslow, A. H. (1964), Religions, Values, and Peak-Experiences, Columbus USA: Ohio State University Press

Pavluska V. (2014), Kultúra marketing, Elméleti alapok, gyakorlati megfontolások, Budapest: Akadémiai Kiadó

Pine, B.J. and Gilmore, J.H. (1999), The Experience Economy. Boston: Harvard Business School Press 
Vincze Dalma PhD hallgató

vinczed@eco.u-szeged.hu

Szegedi Tudományegyetem

\section{Experiences in social media posts in case of young consumers}

\section{THE AIMS OF THE PAPER}

Understanding and researching the function of consumption is considered to be one of the most important tasks in the field of Consumer behavior studies. Our aim is to understand the motivation behind the conspicuous consumption on social media platforms. It can be difficult to understand the motivation behind the consumption of 18-22-years-old consumers.

\section{METHODOLOGY}

It was decided that the best method for this investigation was to conduct photo collage interviews (mixed-method) based netnography (online observation method) beyond the 18-22-year-old Facebook and Instagram users. The length of this investigation was 3 months.

\section{MOST IMPORTANT RESULT}

This 3-month-long investigation made perceivable the main feelings and senses behind the posted pictures. The investigation revealed that these young consumers mainly post pictures that made them happy or proud. These results further our knowledge of experience since our subjects want to consume goods and services that have the ability to provide fun. They like to do this either in alone or in community. At the same time, they want to feel unique and special.

\section{RECOMMENDATIONS}

As a practical proposal, we can confirm that this age group wants to choose services that are able to communicate and provide experience and joy. This motivation should be one part of the marketing communication strategy. Our results can be considered as insights for - mainly spare time activity service providers, which work with the same age of consumers and are open to using these platforms for communication about the services.

Keywords: consumption, experience, netnography, photo collage 